\title{
Tricyclic Antidepressants in Chronic Low Back Pain: A Review
}

\author{
Dzikrina Ilmanita ${ }^{1}$ and Hanik Badriyah Hidayati*2 \\ ${ }^{1}$ Faculty of Pharmacy, Airlangga University, Surabaya, Indonesia \\ ${ }^{2}$ Department of Neurology, Dr. Soetomo General Hospital, Surabaya, Indonesia \\ *E-mail: hanikhidayati@yahoo.com
}

\begin{abstract}
Chronic low back pain [LBP] is the frequent chronic pain and notable health problem which is the main reason for disabling conditions, individual suffering, sick leave, and costly treatment. Treatment of chronic LBP consists of pharmacological and non-pharmacological treatment. Tricyclic antidepressants [TCAs], as one of pharmacological treatment, are commonly used for neuropathic pain but the data for neuropathic pain in LBP is limited. The aim of this review is evaluating the effectivity and adverse drug reactions [ADRs] of TCAs in chronic LBP.

We searched scientific search engines including Scopus and PubMed and collected original articles including Randomized Clinical Trial [RCT], comparative, and observational study about TCAs treatment in chronic LBP from 1998 to 2019.

In this review, 5 articles and 543 patients were evaluated. Amitriptyline is the most well-studied TCA for chronic LBP. Both amitriptyline and nortriptyline can reduce pain severity significantly when the dose is increased gradually depending on patient tolerance. However, single-dose imipramine is not superior to placebo. The most prevalence adverse drug reactions [ADRs] of TCAs including dry mouth, somnolence, insomnia, sedation, and constipation. From this study, we can conclude that TCAs can be effective for treating chronic LBP and the dose should be increased gradually depending on the patient's tolerance. The potential benefit and harm should be quantified before using TCAs as an analgesic for chronic LBP.
\end{abstract}

Keywords: chronic low back pain, effectivity, tricyclic antidepressants

\section{Introduction}

Chronic LBP is the frequent chronic pain and notable health problem take on throughout the world [1-3]. Chronic LBP is also considered the most frequent source of disability, in addition to its increasing prevalence [4,5]. Approximately as many as $84 \%$ of individuals have at least an episode of LBP in their lifetime [5,6]. Among $24-61 \%$ of individuals with acute LBP progress into chronic LBP $[1,3,7]$

Chronic LBP is the main reason for disabling conditions, individual suffering, sick leave, and costly treatment $[1,6,8]$. It has a negative effect on the quality of life and also appends the socio-economic burden for individuals and communities [3]. From the economic perspective, the impact of LBP is equivalent to other frequent, high-cost conditions, such as autoimmune, mental health, malignancy, and cardiovascular disease [9]. Unfortunately, available therapy especially oral medicines only beneficial in no more than $50 \%$ of patients $[1,4]$. Some of those oral medicines are related to certain adverse drug reactions which can affect an individual's quality of life [1].

Approximately $30.6 \%$ of chronic LBP's patients experience neuropathic pain and more than $8 \%$ of those patients develop anxiety, sleep disorder, or depression [10]. Antidepressants are commonly used for neuropathic pain with comorbid anxiety or depression but the data regarding antidepressant usage in neuropathic LBP is limited [1]. Many studies concerning LBP have failed to prove antidepressants significance and effectivity. However, a systematic review discovers that some antidepressants which inhibit the reuptake of norepinephrine can reduce chronic LBP complaints [11].

Tricyclic antidepressants [TCAs] can produce an analgesic effect by disturbing norepinephrine and serotonin reuptake in the descending inhibitory system hence augment the amount of those neurotransmitters in the synaptic cleft $[12,13]$. Each TCA has a different effect on monoamine reuptake. Amitriptyline, clomipramine, and imipramine are considered as dual-type TCA because they inhibit both serotonin and norepinephrine reuptake, whereas nortriptyline and 
desipramine are particularly inhibiting norepinephrine reuptake [13-15].

Tricyclic antidepressants have a wide mechanism of action. They can interact with histamine, muscarinic, Nmethyl-D-aspartate [NMDA], and alpha-adrenergic receptors $[12,14]$. Due to unspecific mechanisms, the use of TCAs is limited considering the risk of adverse drug reaction [12]. Hence, although TCAs become first-line therapy for neuropathic pain, proportions of TCAs usage in chronic LBP is relatively smaller than other antidepressants $[10,16]$. This review will discuss both effectivity and ADRs of TCAs treatment in chronic LBP.

\section{Methods}

Two databases [Pubmed, and Scopus] were searched from 1998 to 2019. We include original articles including RCT, comparative, and observational study about TCAs treatment in chronic LBP. The following keywords are used: [["Tricyclic Antidepressants" OR "Amitriptyline" OR "Clomipramine" OR "Imipramine" OR "Nortriptyline" OR "Desipramine"] AND ["chronic low back pain" OR "chronic low backache"]]. Articles with duplicated records, nonEnglish language paper, and irrelevant full text were excluded.

\section{Results}

\subsection{Study selection and characteristic}

The initial search generates 57 articles. After removing duplicates and irrelevant records, 5 articles that were published between 1998 to 2019 were recruited. Totally 534 chronic LBP patients were evaluated. The characteristics of the included studies are displayed in table 1. All recruited articles are RCT. Two studies compare TCAs with placebo, and three studies compare TCAs with active comparators [1721]. Only one study is not blinded [19].

Among all five relevant articles, three of them evaluate amitriptyline treatment in chronic LBP while the rest articles evaluate imipramine and nortriptyline [17-21]. As many as three studies increase the dose gradually based on patient response and side effects [19-21]. The duration of treatment differs in each study [17-21]. The only study regarding imipramine evaluates its immediate analgesic effect [18].

\subsection{Effectiveness of TCAs in chronic LBP}

Amitriptyline (Table 2) is the most studied TCA for chronic LBP $[17,19,20]$. All studies of amitriptyline prove that amitriptyline can reduce pain intensity. Low dose amitriptyline (25mg/ day) which is given for 6 months is able to reduce the severity of pain by 12.6 whereas its comparator (benztropine mesylate) only reduces the severity of pain by $4.8 \mathrm{~mm}$ [17]. The study by Farajirad et al (2014) also finds that amitriptyline $25-150 \mathrm{mg} /$ day can reduce pain scale by 3.5 from the baseline but this study does not mention the pain reduction of its comparator [20]. The same trend is also found when amitriptyline dose is increased from $12.5-50 \mathrm{mg} /$ day where amitriptyline therapy can reduce VAS scores by 3.9. Amitriptyline has a better ability to reduce pain severity in comparison with pregabalin [19].

The clinical study by Atkinson et al (1998) finds that nortriptyline therapy can reduce pain severity by 2.59 points while a placebo can reduce pain severity by 0.91 points [21]. Single-dose imipramine can reduce pain intensity by 1.6 whereas a placebo is also can reduce pain intensity by 1.5 [18]. Therefore, TCAs probably can be effective for treating chronic LBP but the comparator's effect should be carefully considered to determine TCAs effectiveness [17,19-21]. Table 2 displays the outcome of TCAs in the included study.

\subsection{Adverse drug reaction (ADR) of TCAs in chronic LBP}

The most prevalence ADRs including dry mouth, somnolence, insomnia, sedation, and constipation [19-21]. Orthostatic symptoms are quite common in nortriptyline than amitriptyline treatment $[20,21]$. The study reports 17 cases of orthostatic symptoms for nortriptyline while amitriptyline has only one case of orthostatic hypotension [20,21]. The percentage of nortriptyline ADRs is considered to be the highest $(100 \%)$ in our included studies. Table 3 represents ADRs in the included study.

\section{Discussion}

The primary finding of our analysis is TCAs, whether their mechanism inhibits both serotonin and norepinephrine or dominantly inhibits norepinephrine, seem effective to reduce pain symptoms of chronic LBP [19-22]. All studies prove that TCAs can reduce pain severity in chronic LBP even though the pain reduction of some TCAs is not significantly different from the baseline or their comparator. The inconsistent results regarding TCAs effectivity are likely due to the differences in the dosage used, observation time, and the comparator of each study [17-21]. The clinical symptom is also likely contributing to the effectivity of TCAs in chronic LBP patients since those with leg or radicular pain gain better effect of analgesia [21,23]. The clinical study by Atkinson et al (1998) find that nortriptyline therapy has a significant reduction of pain severity especially in patients with radicular pain [21].

The clinical study by Urquhart et al (2018) indicates that low dose amitriptyline $(25 \mathrm{mg} / \mathrm{day})$ which is given for 6 months cannot significantly reduce the severity of pain when compared to the pain baseline [17]. On the other hand, clinical studies by Kalita et al (2014) and Farajirad et al (2013) indicate that titration of amitriptyline dosage from 12.5-50 $\mathrm{mg} /$ day or $25-150 \mathrm{mg} /$ day (depending on patient tolerance) is able to significantly decrease the severity of pain from baseline $[19,20]$. Those results can be due to the fact that TCAs are predicted to have a specific therapeutic window for 
analgesic effect. The mean effective concentration of TCAs are $65 \mathrm{ng} / \mathrm{ml}$ for amitriptyline, $30 \mathrm{ng} / \mathrm{ml}$ for nortriptyline, and $<60 \mathrm{ng} / \mathrm{ml}$ for desipramine [24,25]. If the dose and blood concentrations are out of the therapeutic range, the analgesic outcome does not occur [24]. The dose which is used by Urquhart et al (25 mg/day) is out of the range of TCAs' effective dose for analgesia in common neuropathic pain or neuropathic pain in LBP. Literature mentions the effective dose of TCAs for analgesia is between $50-150 \mathrm{mg} /$ day [23]. Although $25 \mathrm{mg} /$ day is not clinically or statistically significant for reducing pain severity, patients still experience 12.5 point pain reduction and a significance improved in disability, so probably dose titration may be worth considering for improving TCAs effectivity [17]. In animal-study, the lower dose of TCA approximately 2-4 fold lower than the dose for depression, is probably sufficient to terminate neuropathic allodynia [26]. When amitriptyline is compared with pregabalin, some patients only use $37.5 \pm 12.9 \mathrm{mg}$ of amitriptyline to experience significant pain reduction while at the same time, the other patients don't experience significant pain reduction although they use relatively the same dose
(38.8 $\pm 12.7 \mathrm{mg} /$ day) [19]. Therefore, the other clinical and concentration-controlled trial is still required to find the optimal dose and therapeutic window of TCAs analgesic effect $[17,25]$.

The clinical study by Schliessbach et al (2018) shows that single-dose imipramine does not provide a satisfactory analgesic effect in comparison with the placebo, probably because of insufficient dose or non-effectiveness of imipramine [18]. Preclinical study reveals TCAs' analgesic onset does not appear immediately after acute used but is delayed following 7-14 days of chronically used [22,26-28]. TCAs need time to influence the occurrence of molecular plasticity, hence, the onset of analgesic effect delays for several days after the first treatment $[22,28]$. The use of a single-dose of imipramine is debatable, considering the possibility of the delayed analgesic onset of TCAs [18]. However, imipramine may possibly be beneficial for chronic LBP mainly with comorbid depression even though its effectivity may not be yield from the classical mechanism [18,29].

Table 1

Characteristic of the induced study

\begin{tabular}{|c|c|c|c|c|c|c|}
\hline $\begin{array}{l}\text { Author } \\
\text { (Year) }\end{array}$ & Setting & Treatment & Comparator & $\begin{array}{c}\text { Duration of } \\
\text { treatment }\end{array}$ & $\begin{array}{l}\text { Type of } \\
\text { Study }\end{array}$ & $\begin{array}{l}\text { Number of } \\
\text { Patient } \\
\text { withdraws }\end{array}$ \\
\hline $\begin{array}{l}\text { Urquhart et } \\
\text { al (2018) }\end{array}$ & $\begin{array}{c}\text { Randomized, } \\
\text { double-blind } \\
(\mathrm{N}=146)\end{array}$ & $\begin{array}{c}\text { Amitriptyline } 25 \\
\text { mg/day }\end{array}$ & $\begin{array}{l}\text { Benztropine } \\
\text { mesylate, } \\
1 \mathrm{mg} / \text { day }\end{array}$ & 6 months & $\begin{array}{l}\text { Randomized } \\
\text { clinical trial }\end{array}$ & 28 patients \\
\hline $\begin{array}{l}\text { Schliessbach } \\
\text { et al (2018) }\end{array}$ & $\begin{array}{l}\text { Randomized, } \\
\text { double-blinded, } \\
\text { placebo- } \\
\text { controlled design } \\
(\mathrm{N}=50)\end{array}$ & $\begin{array}{c}\text { Imipramine } \\
75 \mathrm{mg} \\
\text { (single- dose) }\end{array}$ & $\begin{array}{l}\text { Tolterodine } \\
1 \mathrm{mg}\end{array}$ & 2 hours & $\begin{array}{l}\text { Randomized } \\
\text { controlled } \\
\text { trial }\end{array}$ & 19 patients \\
\hline $\begin{array}{l}\text { Kalita et al } \\
\quad(2014)\end{array}$ & $\begin{array}{l}\text { Randomized, } \\
\text { single-center } \\
\quad(\mathrm{N}=200)\end{array}$ & $\begin{array}{c}\text { Amitriptyline } \\
12.5 \mathrm{mg} \\
\text { bedtime }(2 \\
\text { weeks }) \rightarrow 25 \mathrm{mg} \\
(4 \text { weeks }) \rightarrow 50 \\
\mathrm{mg}\end{array}$ & $\begin{array}{c}\text { Pregabalin } 75 \\
\text { mg bid ( } 2 \\
\text { weeks) } \rightarrow 150 \\
\text { mg bid ( } 4 \\
\text { weeks) } \rightarrow 300 \\
\text { mg bid }\end{array}$ & 14 weeks & $\begin{array}{l}\text { Randomized } \\
\text { controlled } \\
\text { open-labeled } \\
\text { trial }\end{array}$ & 53 patients \\
\hline $\begin{array}{l}\text { Farajirad et } \\
\text { al (2013) }\end{array}$ & $\begin{array}{l}\text { Randomized, } \\
\text { single blind } \\
\quad(\mathrm{N}=60)\end{array}$ & $\begin{array}{l}\text { Amitriptyline } 25 \\
\text { mg/day } \rightarrow \text { up to } \\
150 \mathrm{mg} / \text { day }^{\mathrm{a}}\end{array}$ & $\begin{array}{c}\text { Sustained- } \\
\text { release } \\
\text { bupropion } 150 \\
\text { mg/day } \rightarrow 150 \\
\text { mg bid }\end{array}$ & $2-8$ weeks & $\begin{array}{l}\text { Prospective } \\
\text { clinical } \\
\text { trial. }\end{array}$ & Not specified \\
\hline $\begin{array}{l}\text { Atkinson et } \\
\text { al (1998) }\end{array}$ & $\begin{array}{l}\text { Randomized, } \\
\text { double blind, } \\
\text { placebo- } \\
\text { controlled } \\
(\mathrm{N}=78)\end{array}$ & $\begin{array}{c}\text { Nortriptyline } 25 \\
\text { mg/day ( } 3 \text { days) } \\
\rightarrow 50 \mathrm{mg} / \text { day (4 } \\
\text { days }) \rightarrow 75 \mathrm{mg} \\
(3 \text { days }) \rightarrow 100 \\
\text { mg }(4 \text { days })^{\mathrm{a}}\end{array}$ & Placebo capsule & 8 weeks & $\begin{array}{l}\text { Placebo- } \\
\text { controlled } \\
\text { randomized } \\
\text { clinical trial }\end{array}$ & 21 patients \\
\hline
\end{tabular}

Abbreviations: bid= bis in die (twice daily); $\mathrm{mg}=$ milligrams

a The dose is adjusted depending on the patient's tolerance 
Table 2

Outcome in the included study

\begin{tabular}{|c|c|c|c|c|c|c|}
\hline \multirow[t]{2}{*}{ Author (Year) } & \multirow[t]{2}{*}{ TCAs (Dose) } & \multirow[t]{2}{*}{ Pain Scale } & \multicolumn{2}{|c|}{ Pain baseline } & \multicolumn{2}{|c|}{$\begin{array}{l}\text { Pain difference } \\
\text { (Pre-Post) }\end{array}$} \\
\hline & & & TCA & Comparator & TCA & Comparator \\
\hline $\begin{array}{c}\text { Urquhart et al } \\
\text { (2018) }\end{array}$ & $\begin{array}{c}\text { Amitriptyline (25 } \\
\text { mg/day) }\end{array}$ & $\begin{array}{c}\text { VAS } \\
(0-100 \mathrm{~mm})\end{array}$ & $39.8 \mathrm{~mm}$ & $43.4 \mathrm{~mm}$ & $\begin{array}{l}12.6 \\
\mathrm{~mm}\end{array}$ & $\begin{array}{l}4.8 \\
\mathrm{~mm}\end{array}$ \\
\hline $\begin{array}{l}\text { Schliessbach et } \\
\text { al (2018) }\end{array}$ & $\begin{array}{l}\text { Imipramine (75 } \\
\mathrm{mg})\end{array}$ & $\begin{array}{l}\text { NRS } \\
(0-10)\end{array}$ & 4.2 & 4.0 & 1.6 & 1.5 \\
\hline $\begin{array}{l}\text { Kalita et al } \\
\quad(2014)\end{array}$ & $\begin{array}{c}\text { Amitriptyline (12. } \\
5-50 \mathrm{mg} / \text { day) }\end{array}$ & $\begin{array}{l}\text { VAS } \\
(0-10)\end{array}$ & 6.7 & 6.7 & 3.9 & 2.9 \\
\hline $\begin{array}{c}\text { Farajirad et al } \\
\text { (2013) }\end{array}$ & $\begin{array}{c}\text { Amitriptyline } \\
(25-150 \mathrm{mg} / \text { day })\end{array}$ & $\begin{array}{l}\text { Pain rating } \\
\text { scale }\end{array}$ & $\begin{array}{c}<5(25 \% \text { of } \\
\text { patients }) \\
<7.5(50 \% \text { of } \\
\text { patients }) \\
<8(75 \% \text { of } \\
\text { patients })\end{array}$ & Not reported & 3.5 & Not reported \\
\hline $\begin{array}{c}\text { Atkinson et al } \\
\text { (1998) }\end{array}$ & $\begin{array}{l}\text { Nortriptyline (25- } \\
100 \mathrm{mg} / \text { day) }\end{array}$ & $\begin{array}{c}\text { DDS-I } \\
(0-21 \text { points })\end{array}$ & 11.66 & 9.95 & 2.59 & 0.91 \\
\hline
\end{tabular}

Abbreviations: TCA= Tricyclic Antidepressant; VAS= Visual Analog Scale; NRS= Numerical Rating Scale; DDS-I: Descriptor Differential Scale Pain Intensity

Table 3

Adverse drug reaction (ADR) in the included study

\begin{tabular}{|c|c|c|c|}
\hline Author (Year) & TCA & $\% \mathrm{ADR}$ & ADR (n) \\
\hline $\begin{array}{l}\text { Urquhart et al } \\
\text { (2018) }\end{array}$ & Amitriptyline & $34.7 \%$ & Not specified \\
\hline $\begin{array}{c}\text { Schliessbach et al } \\
\text { (2018) }\end{array}$ & Imipramine & Not reported & Nausea, dizziness, and sedation (not differ from placebo) \\
\hline Kalita et al (2014) & Amitriptyline & $\begin{array}{c}17.5 \% \\
(18 \text { patients })\end{array}$ & $\begin{array}{l}\text { Sedation }(n=10) \text {, unsteadiness }(n=2) \text {, dry mouth }(n=3) \text {, and } \\
\text { vertigo }(n=2)\end{array}$ \\
\hline $\begin{array}{l}\text { Farajirad et al } \\
\qquad(2013)\end{array}$ & Amitriptyline & $43.3 \%$ & $\begin{array}{l}\text { Dry mouth, somnolence, constipation, orthostatic hypotension, } \\
\text { and nausea }\end{array}$ \\
\hline $\begin{array}{l}\text { Atkinson et al } \\
\quad(1998)\end{array}$ & Nortriptyline & $\begin{array}{c}100 \% \\
\text { (28 patients) }\end{array}$ & $\begin{array}{l}\text { Dry mouth }(n=23) \text {, insomnia }(n=20) \text {, sedation }(n=17) \text {, } \\
\text { orthostatic symptoms }(n=17) \text {, constipation }(n=12) \text {, increased } \\
\text { sweating }(n=9) \text {, and palpitations }(n=3)\end{array}$ \\
\hline
\end{tabular}

Abbreviations: $\mathrm{TCA}=$ Tricyclic Antidepressant; ADR= Adverse Drug Reaction

The comparator of each study may contribute to the insignificance of amitriptyline. The study by Kalita et al (2014) proves that amitriptyline can significantly reduce pain intensity when compared with pregabalin [19]. Atkinson et al (2018) also prove that nortriptyline reduces the pain intensity significantly in comparison with a placebo [21]. The studies which are not able to demonstrate amitriptyline's significance to the comparator are the study by Urquhart et al (2018) and Farajirad et al (2013). Those studies use active comparators, such as benztropine mesylate which has sedation effect, or bupropion which has antidepressant effects through the inhibition of dopamine or norepinephrine reuptake [17,20,22]

Patients who have used antidepressants are more possible to recover from chronic LBP symptoms than those using a placebo but those patients also experience a higher incidence of adverse effects [30]. Dry mouth, insomnia, sedation, and constipation are the most frequent ADRs in our included study (Table 3) [19-21]. Those ADRs are linked with TCAs mechanism in muscarinic cholinergic receptors [12,31]. The result of our study is in line with some systematic reviews $[30,32,33]$. A systematic review suggests strong evidence regarding dry mouth and constipation as ADRs of amitriptyline and desipramine, also constipation, insomnia, and drowsiness as ADRs of nortriptyline [32].

The percentage of nortriptyline ADRs is considered to be the highest $(100 \%)$ in our included studies (Table 3). However, Atkinson et al (1998) find that nortriptyline's ADRs are not statistically different from the placebo's ADRs [21]. In 
a meta-analysis, after the placebo effect is adjusted, amitriptyline and desipramine show a high risk of adverse effects just like nortriptyline [32]. Placebo adverse effect is somewhat high in patients with chronic pain, maybe indicating escalated anticipation and awareness of adverse effects in those patients [32].

TCAs may lengthen QT intervals and cause orthostatic hypotension so that should be cautiously used in comorbid cardiac diseases. TCAs can be lethal if accidentally or deliberately used in excessive doses [34]. The mechanism which is responsible for orthostatic hypotension through the inhibition of $\alpha 1$-noradrenergic receptors. This mechanism is also responsible for tachycardia and dizziness incident [31] The study of nortriptyline finds a relatively high incidence of orthostatic symptoms but it is categorized as weak evidence $[21,32]$. In contrast to studies of TCAs in depressed patients, serious undesirable effects, such as prolonged-QT intervals or hypotension, were not clearly observed in a meta-analysis about chronic pain, probably because the analgesic treatment uses lower doses compared to depression treatment [32]. The adverse effect of TCAs usually dose-dependent [31]. In our analysis, the study of nortriptyline reports 17 cases of orthostatic symptoms may be due to the dose which is in the therapeutic window for treating major depression [21].

\subsection{Limitation}

This study actually analyzes all TCAs including desipramine and clomipramine but our method could not obtain the study of desipramine and clomipramine in chronic LBP. Moreover, we do not get clear evidence about the long term effect of imipramine, which emphasizes that further study is required to validate the effectiveness of the TCAs group for chronic LBP.

\section{Conclusion}

In summary, our review indicates that TCAs can be effective for treating chronic LBP and the dose of TCAs should be increased gradually depending on patient tolerance. TCAs can cause some adverse drug reactions, for example, dry mouth, constipation, insomnia, and sedation. In regard to more serious ADRs (i.e. orthostatic symptom) is likely dosedependent hence it can be safely used when the dose is lower compared to depression treatment. Although TCAs seems effective for treating chronic LBP, the potential benefit and harm should be quantified before using TCAs as an analgesic for chronic LBP. Further studies are required to confirm the optimal dose of TCAs for analgesia in chronic LBP.

\section{References}

[1] Baron R, Binder A, Attal N, Casale R, Dickenson AH, Treede R-D. Neuropathic low back pain in clinical practice. Eur J Pain. 2016;20(6):861-73.
[2] Almeida MO, Yamato TP, Parreira P do CS, Costa LOP, Kamper S, Saragiotto TB. Overall confidence in the results of systematic reviews on exercise therapy for chronic low back pain: a cross-sectional analysis using the Assessing the Methodological Quality of Systematic Reviews (AMSTAR) 2 tool. Brazilian J Phys Ther. 2019;

[3] Sitthipornvorakul E, Klinsophon T, Sihawong R, Janwantanakul P. The effects of walking intervention in patients with chronic low back pain: A meta-analysis of randomized controlled trials. Musculoskelet Sci Pract. 2018;34(December 2017):38-46.

[4] Bhangare KP, Kaye AD, Knezevic NN, Candido KD, Urman RD. An Analysis of New Approaches and Drug Formulations for Treatment of Chronic Low Back Pain. Anesthesiol Clin. 2019;35(2):341-50.

[5] Yeganeh M, Baradaran HR, Qorbani M, Moradi Y, Dastgiri S. The effectiveness of acupuncture, acupressure and chiropractic interventions on treatment of chronic nonspecific low back pain in Iran: A systematic review and meta-analysis. Complement Ther Clin Pract. 2017;27(2017):11-8.

[6] Ehrenbrustho K, Ryan CG, Grüneberg C, Martin DJ. A systematic review and meta-analysis of the reliability and validity of sensorimotor measurement instruments in people with chronic low back pain. Musculoskelet Sci Pract. 2018;35(2018):73-83.

[7] Saragiotto BT, Machado GC, Ferreira ML, Pinheiro MB, Shaheed CA, Maher CG. Paracetamol for low back pain. Cochrane Database Syst Rev. 2016;(6).

[8] Meucci RD, Fassa AG, Faria NMX. Prevalence of chronic low back pain: systematic review. Rev Saude Publica. 2015;49:1.

[9] Hartvigsen J, Hancock MJ, Kongsted A, Louw Q, Ferreira ML, Genevay S, et al. What low back pain is and why we need to pay attention. Lancet. 2018;391(10137):2356-67.

[10] Gore M, Sadosky A, Stacey BR, Tai K, Leslie D. The Burden of Chronic Low Back Pain. Spine (Phila Pa 1976). 2012;37(11):E668-77.

[11] Müller-Schwefe G, Morlion B, Ahlbeck K, Alon E, Coaccioli S, Coluzzi F, et al. Treatment for chronic low back pain: the focus should change to multimodal management that reflects the underlying pain mechanisms. Curr Med Res Opin. 2017;33(7):1199-210.

[12] Urits I, Peck J, Orhurhu MS, Wolf J, Patel R, Orhurhu $\mathrm{V}$, et al. Off-label Antidepressant Use for Treatment and Management of Chronic Pain : Evolving Understanding and Comprehensive Review. Curr Pain Headache Rep. 2019;23(9):66.

[13] Mika J, Zychowska M, Makuch W, Rojewska E, Przewlocka B. Neuronal and immunological basis of action of antidepressants in chronic pain - clinical and experimental studies. Pharmacol Reports. 2013;65(6):1611-21.

[14] Sindrup SH, Otto M, Finnerup NB, Jensen TS. Antidepressants in the treatment of neuropathic pain. Basic Clin Pharmacol Toxicol. 2005;96(6):399-409.

[15] Obata H. Analgesic mechanisms of antidepressants for 
neuropathic pain. Int J Mol Sci. 2017 Nov;18(11):2483.

[16] Gustavsson A, Bjorkman J, Ljungcrantz C, Rhodin A, Rivano-fischer M, Sjolund K-F, et al. Pharmacological Treatment Patterns in Neuropathic Pain — Lessons from Swedish Administrative Registries. Pain Med. 2013;14(7):1072-80.

[17] Urquhart DM, Wluka AE, Tulder M Van, Heritier S, Forbes A, Fong C, et al. Efficacy of Low-Dose Amitriptyline for Chronic Low Back Pain. JAMA Intern Med. 2019;178(11):1474-81.

[18] Schliessbach J, Siegenthaler A, Butikofer L, Limacher A, Juni P, Vuilleumier PH, et al. Effect of single-dose imipramine on chronic low-back and experimental pain. A randomized controlled trial. PLoS One. 2018;13(5):e0195776.

[19] Kalita J, Kohat AK, Misra UK, Bhoi SK. An open labeled randomized controlled trial of pregabalin versus amitriptyline in chronic low backache. J Neurol Sci. 2014;342(1-2):127-32.

[20] Farajirad S, Behdani F, Hebrani P, Farajirad M. Comparison Between the Effects of Amitriptyline and Bupropione on the Quality of Life and the Reduction in the Severity of Pain in Patients With Chronic Low-Back Pain. Neurosurg Q. 2013;23(4):227-9.

[21] Atkinson JH, Slater MA, Williams RA, Zisook S, Patterson TL, Grant I, et al. A placebo-controlled randomized clinical trial of nortriptyline for chronic low back pain. Pain. 1998;76(3):287-96.

[22] Kremer M, Salvat E, Muller A, Yalcin I, Barrot M. Antidepressants and gabapentinoids in neuropathic pain : mechanistic insights. Neuroscience. 2016;338:183-206.

[23] Orbai A, Meyerhoff JO. The Effectiveness of Tricyclic Antidepressants on Lumbar Spinal Stenosis. 2010;68(1):39-41.

[24] Watson CP. Therapeutic window for amitriptyline analgesia. Can Med Assoc J. 1984;130(2):105-6.

[25] Atkinson JH, Slater MA, Capparelli E V, Wallace MS Zisook S, Abramson I, et al. Efficacy of noradrenergic and serotonergic antidepressants in chronic back pain: a preliminary concentration-controlled trial. J Clin Psychopharmacol. 2007;27(2):135-42.

[26] Benbouzid M, Choucair-jaafar N, Yalcin I, Waltisperger E, Muller A, Freund-Mercier MJ, et al. Chronic, but not acute, tricyclic antidepressant treatment alleviates neuropathic allodynia after sciatic nerve cuffing in mice. Eur J Pain. 2008;12(8):1008-17.

[27] Barrot M, Yalcin I, Tessier L, Freund-Mercier MJ. Antidepressant treatment of neuropathic pain: looking for the mechanism. Future Neurol. 2010;5(2):247-57.

[28] Kusuda R, Ravanelli MI, Cadetti F, Franciosi A, Previdelli K, Zanon S, et al. Long-Term Antidepressant Treatment Inhibits Neuropathic Pain-Induced CREB and PLC\&gamma; -1 Phosphorylation in the Mouse Spinal Cord Dorsal Horn. J Pain. 2013;14(10):1162-72.

[29] Alcoff J, Jones E, Rust P, Newman R. Controlled Trial of Imipramine for Chronic Low Back Pain. J Fam Pract. 1982;14(5):841-6.

[30] Salerno SM, Browning R, Jackson JL. The Effect of Antidepressant Treatment on Chronic Back Pain. Arch Intern Med. 2002;162(1):19-24.

[31] Perrot S, Javier R, Marty M, Jeunne C Le, Laroche F. Is there any evidence to support the use of anti-depressants in painful rheumatological conditions? Systematic review of pharmacological and clinical studies. Rheum. 2008;47(8):1117-23.

[32] Riediger C, Schuster T, Barlinn K, Maier S, Weitz J, Siepmann T. Adverse Effects of Antidepressants for Chronic Pain: A Systematic Review and Meta-analysis. Front Neurol. 2017;8:307.

[33] van den Driest JJ, Bierma-Zeinstra SMA, Bindels PJE, Schiphof D. Amitriptyline for musculoskeletal complaints: a systematic review. Fam Pract. 2017;34(2):138-46.

[34] Argoff C. Mechanisms of pain transmission and pharmacologic management. Curr Med Res Opin. 2011;27(10):2019-31. 